\title{
INFLUENCE OF CELLULOSE PARTICLES ON CHEMICAL RESISTANCE, MECHANICAL AND THERMAL PROPERTIES OF EPOXY COMPOSITES
}

\author{
N.V. Sigareva ${ }^{1}$, V.A. Barbash ${ }^{2}$, O.V. Yashchenko ${ }^{2}$, S.V. Shulga ${ }^{1}$, \\ D.L. Starokadomsky ${ }^{1}$, B.M. Gorelov ${ }^{1}$ \\ ${ }^{I}$ Chuiko Institute of Surface Chemistry of National Akademy of Science of Ukraine, \\ 17 General Naumov st., Kyiv, 03164, Ukraine \\ e-mail: microft2@ukr.net \\ ${ }^{2}$ National Technical University of Ukraine "Igor Sikorsky Kyiv Polytechnic Institute", \\ 37 Prosp. Peremohy, Kyiv, 03056, Ukraine \\ e-mail:v.barbash@kpi.ua \\ Submitted November 06, 2019 \\ Accepted March 02, 2020
}

Background: The technological developments for nanocellulose production from cheaper plant materials compared to wood, in particular, agricultural waste is an urgent task of nanobiophysics. The discovery of possibility of expanding the functional characteristics of materials in compositions with modified cellulose particles essentially stimulated the interest of researchers in cellulose composites. Surface modification of cellulose particles by functional materials, such as dyes, metal oxides, silicon, allows applying composites with modified cellulose in various areas of modern industry. A significant improvement in the operational performances of functionalized cellulose particles can be achieved by using them as filler in polymers. Epoxy resin compositions with modified and unmodified cellulose particles, studied in present work, are an example of hybrid biosystem. The interfacial interaction of filler particles with the epoxy matrix, their concentration and dispersion can change the physical and chemical properties of the biopolymer and the functional parameters of biocomposites. Studying the influence of external fields on the physical and chemical properties of epoxy resin-based biosystems and their influence on operational parameters seems to be an urgent problem of advanced and sustained materials science.

Objectives: The purpose of this work was to develop an effective nanocellulose synthesis from plant materials and surface functionalization of micro- and nanocellulose particles with clathrochelate iron (II) dye as well obtaining biocompositions of epoxy resin with functionalized and non-functionalized microand nanocellulose, and to explore of the morphology, chemical resistance, mechanical and thermal properties of epoxy composites with cellulose micro and nanoparticles.

Materials and methods: The studying objects were the composites of epoxy resin Eposir-7120 with a polyethylene polyamine "PEPA" hardener in a ratio of $6.2: 1$ and $10 \%$ cellulose micro and nanoparticles. The microcellulose obtained from wood has been a commercial product. Nanocellulose has been synthesized from organosolv cellulose obtained from Miscanthus $x$ giganteus stalks. Surface modification of micro- and nanocellulose was performed using the clathrochelate iron (II) dye. The specific surface area of cellulose particles was determined using low-temperature nitrogen adsorption-desorption according to the Brunauer-Emmett-Teller method. Mechanical parameters were determined using universal Shopper and UMM-10 machines. Thermal analysis was performed using Q1500 analyzer. Swelling was determined by the gravimetric method.

Results: Elastic modulus $E$, compressive strength $\sigma$ and thermogravimetric parameters were determined. It was shown that in composites with micro and nanocellulose the $E$ rises in $7.0-12.2 \%$ while the $\sigma$ increases in $9.1 \%$ for composites with cellulose micro particles. The loading resin with nanocellulose and modified cellulose microparticles no affects the $\sigma$ value of composites. The thermal stability of epoxy polymer $\left(310^{\circ} \mathrm{C}\right)$ reduces after loading with micro and nanocellulose to 290 and $300^{\circ} \mathrm{C}$, respectively. Chemical resistance of composites with both celluloses to $20 \%$ nitric acid reduces. In neutral medium swelling characterizes by rapid sorption to saturation of $15-20 \%$ acetone in 36 hours.

Conclusions: Thus, the synthesis method of nanocellulose from plant materials and functionalization of its surface with clathrochelate iron (II) were developed. Light response of dye was detected in visible spectral range. Epoxy resin composites with 10\% micro and nanocellulose were obtained. The filling

(C) Sigareva N.V., Barbash V.A., Yashchenko O.V., Shulga S.V., Starokadomsky D.L., Gorelov B.M., 2020 
effect with micro- and nanocellulose at elastic modulus, compressive strength, and thermal stability of epoxycomposites was studied. The swelling processes run similarly in composites with cellulose micro and nanoparticles.

KEY WORDS: epoxy composite; microcellulose; nanocellulose; synthesis; mechanical parameters; thermal parameters; chemical resistance.

\section{ВПЛИВ ЧАСТИНОК ЦЕЛЮЛОЗИ НА ХІМІЧНУ СТІЙКІСТЬ, МЕХАНІЧНІ ТА ТЕРМІЧНІ ВЛАСТИВОСТІ ЕПОКСИДНИХ КОМПОЗИТІВ Н.В. Сігарьова ${ }^{1}$, В.А. Барбаш ${ }^{2}$, О.В. Ященко ${ }^{2}$ С.В. Шульга ${ }^{1}$, Д.Л. Старокадомський ${ }^{1}$, Б.М. Горєлов ${ }^{1}$ \\ Iнститут хімії поверхні ім. О.О. Чуйко Наиіональної академії наук Украӥни, вул. Генерала Наумова, 17, м. Київ, 03164, Украӥна}

${ }^{2}$ Національний технічний університет Украӥни «Київський політехнічний інститут імені Ігоря Сікорського», просп. Перемоги, 37, м. Київ, 03056, Украӥна

Актуальність: Технологічні розробки для виробництва наноцелюлози 3 дешевших рослинних матеріалів у порівнянні з деревиною, зокрема, сільськогосподарськими відходами, є актуальним завданням сучасної нанобіофізики. Відкриття можливості розширення функціональних характеристик матеріалів у композиціях 3 модифікованими частинками целюлози по суті стимулювало інтерес дослідників до целюлозних композитів. Модифікація поверхні частинок целюлози функціональними матеріалами, такими як барвники, оксиди металів, кремній, дозволяє застосовувати композити 3 модифікованою целюлозою в різних областях сучасної промисловості. Істотне поліпшення експлуатаційних параметрів функціоналізованих частинок целюлози можна отримати, використовуючи їх в полімерах в якості наповнювачів. Прикладом гібридних біокомпозитів $є$ вивчені у даній роботі композити епоксидної смоли з частинками модифікованої та немодифікованої целюлози. Міжфазна взаємодія частинок наповнювача 3 епоксидною матрицею, їх концентрація та дисперсність можуть змінювати фізико-хімічні властивості біополімеру та функціональні параметри біокомпозитів. Дослідження впливу зовнішніх чинників на фізико-хімічні властивості біосистем на основі епоксидної смоли та їх вплив на експлуатаційні параметри є актуальною проблемою сучасного матеріалознавства.

Мета роботи: розробка ефективного синтезу наноцелюлози з рослинних матеріалів та проведення функціоналізації поверхні мікро- та наноцелюлозних частинок клатрохелатом заліза (II), отримання біокомпозицій епоксидної смоли 3 вихідною та функціоналізованою мікро та наноцелюлозою, дослідження морфології, хімічної стійкості, механічних та термічних властивостей епоксидних композитів з мікро- та наночастинками целюлози.

Матеріали та методи. Об'єктами дослідження були композити епоксидної смоли Eposir-7120 3 поліетиленполіаміновим затверджувачем "РЕРА" у співвідношенні 6,2:1 та 10\% мікро- та наночастинок целюлози. Мікроцелюлоза, отримана 3 деревини, була комерційним продуктом. Наноцелюлоза синтезована 3 органосольвентної целюлози, отриманої зі стебел Miscanthus $x$ giganteus. Модифікацію поверхні мікро- та наноцелюлози проводили барвником клатрохелатомзаліза (II). Питому поверхню частинок целюлози визначали за допомогою низькотемпературної адсорбції-десорбції азоту за методом Брунауера-Еммета-Теллера. Механічні параметри визначали за допомогою універсальних машин Shopper та UMM-10. Тепловий аналіз провели за допомогою деріватографа Q1500. Набухання досліджували гравіметричним методом.

Результати. Визначено модуль пружності $E$, міцність на стиск $\sigma$ та термогравіметричні параметри. Показано, що в композитах з мікро- та наноцелюлозою $E$ підвищується на 7,0-12,2\%, а $\sigma$ збільшується на $9,1 \%$ для композитів з мікрочастинками целюлози. Наповнення смоли наночастинками целюлози та модифікованої мікроцелюлози не впливає на значення $\sigma$ композитів. Термічна стабільність епоксидного полімеру $\left(310^{\circ} \mathrm{C}\right)$ знижується після наповнення мікро- та наноцелюлозою до 290 та $300^{\circ} \mathrm{C}$ відповідно. Хімічна стійкість епоксикомпозитів 3 мікро- та наноцелюлозою до 20\%-ї азотної кислоти знижується. У нейтральному середовищі процес набухання епоксикомпозитів характеризується швидкою сорбцією до насичення 15-20\% ацетоном за 36 годин.

Висновки. Таким чином, розроблено метод синтезу наноцелюлози з рослинних матеріалів та проведена функціоналізація іiі поверхні клатрохелатом заліза (II). Світлова реакція адсорбованого барвника виявлена у видимому спектральному діапазоні. Отримані композити епоксидної смоли 3 10\% мікро- та наноцелюлози. Вивчено вплив наповнення мікро- та наноцелюлозою на модуль пружності, міцність на стиск, термічну стійкість епоксикомпозитів. Процеси набухання відбуваються аналогічно у композитах з мікро- та наноцелюлозою. 
КЛЮЧОВІ СЛОВА: епоксикомпозит; мікроцелюлоза; наноцелюлоза; синтез; механічні параметри; термічні параметри; хімічна стійкість.

\author{
ВЛИЯНИЕ ЦЕЛЛЮЛОЗНЫХ ЧАСТИЦ НА ХИМИЧЕСКУЮ СТОЙКОСТЬ, \\ МЕХАНИЧЕСКИЕ И ТЕРМИЧЕСКИЕ СВОЙСТВА ЭПОКСИДНЫХ КОМПОЗИТОВ \\ Н.В. Сигарёва ${ }^{1}$, В.А. Барбаш'르. О.В. Ященко ${ }^{2}$, С.В. Шульга ${ }^{1}$, \\ Д.Л. Старокадомский ${ }^{1}$, Б.М. Горелов 1 \\ ${ }^{1}$ Институт химии поверхности им. А.А. Чуйко Национальной академии наук Украины, \\ ул. Генерала Наумова, 17, г. Киев, 03164, Украина \\ ${ }^{2}$ Национальный технический университет Украины «Киевский политехнический институт \\ им. Игоря Сикорского», просп. Победы, 37, г. Киев, 03056, Украина
}

\begin{abstract}
Актуальность: Технологические разработки производства наноцелюлозы из более дешевых растительных материалов по сравнению с древесиной, в частности, сельскохозяйственными отходами, являются актуальной задачей современной нанобиофизики. Открытие возможности расширения функциональных характеристик материалов в композициях с модифицированными частицами целлюлозы существенно стимулировало интерес исследователей к целлюлозным композитам. Модификация поверхности частиц целлюлозы функциональными материалами, такими как красители, оксиды металлов, кремний позволяет применять композиты с модифицированной целлюлозой в различных областях современной промышленности. Существенное улучшение эксплуатационных параметров функционализированных частиц целлюлозы можно достичь, используя их в полимерах в качестве наполнителя. Примером гибридных биокомпозитов являются изученные в данной работе композиты эпоксидной смолы с частицами модифицированной и немодифицированной целлюлозы. Межфазное взаимодействие частиц наполнителя с эпоксидной матрицей, их концентрация и дисперсность могут изменять физико-химические свойства биополимера и эксплуатационные параметры биокомпозитов. Исследование влияния внешних воздействий на физико-химические свойства биосистем на основе эпоксидной смолы и их эксплуатационные параметры представляется актуальной проблемой современного материаловедения.

Цель работы: разработка эффективного синтеза наноцелюлозы из растительных материалов, проведение функционализации поверхности частиц микро- и наноцелюлозы клатрохелатом железа (II), получение биокомпозитов эпоксидной смолы с функционализированной и нефункционализированной микро- и наноцелюлозой, и исследование морфологии, химической стойкости, механических и термических свойств эпоксидных композитов с микро- и наночастицами целлюлозы.
\end{abstract}

Материалы и методы. Объектами исследования были композиты эпоксидной смолы Eposir-7120 с полиэтиленполиаминовым отвердителем "РЕРА” в соотношении 6,2:1 и 10\% микроцеллюлозы и наночастиц целлюлозы. Микроцеллюлоза, полученная из древесины, была коммерческим продуктом. Наноцелюлоза синтезирована из органосольвентной целлюлозы, полученной из стеблей Miscanthus x giganteus. Модификацию поверхности микро- и наноцелюлозы проводили красителем - клатрохелатом железа (II). Удельную поверхность частиц целлюлозы определяли с помощью низкотемпературной адсорбции-десорбции азота по методу Брунауэра-Эммета-Теллера. Механические параметры определяли с помощью универсальных машин Shopper и UMM-10. Тепловой анализ выполняли с помощью дериватографа Q1500. Набухание определяли гравиметрическим методом.

Результаты. Определены модуль упругости $E$, прочность на сжатие $\sigma$ и термогравиметрические параметры. Показано, что в композитах с микро- и наноцелюлозой $E$ повышается на 7,0-12,2\%, а $\sigma$ увеличивается на 9,1\% для композитов с микрочастицами целлюлозы. Наполнение смолы наноцеллюлозой и модифицированной микроцеллюлозой не влияет на величину $\sigma$ композитов. Термическая стабильность эпоксидного полимера $\left(310^{\circ} \mathrm{C}\right)$ снижается после наполнения микро- и наноцелюлозой до 290 и $300^{\circ} \mathrm{C}$ соответственно. Химическая стойкость эпоксикомпозитов с микрои наноцелюлозой к 20\%-й азотной кислоте снижается. В нейтральной среде процесс набухания характеризуется быстрой сорбцией до насыщения 15-20\% ацетоном за 36 часов.

Выводы. Таким образом, разработан метод синтеза наноцелюлозы из растительных материалов и проведена функционализация ее поверхности клатрохелатом железа (II). Световая реакция адсорбированного красителя обнаружена в видимом спектральном диапазоне. Получены композиты эпоксидной смолы с 10\% микро- и наноцеллюлозы. Изучено влияние наполнения микро- и наноцелюлозой на модуль упругости, прочности на сжатие, термическую стойкость 
эпоксикомпозитов. Процессы набухания протекают аналогично в композитах с микро- и наноцеллюлозой.

КЛЮЧЕВЫЕ СЛОВА: эпоксикомпозит; микроцеллюлоза; наноцеллюлоза; синтез; механические параметры; термические параметры; химическая стойкость.

The development of a technology for the production of micro and nanocellulose from cheaper plant materials compared to wood, in particular, agricultural waste is an urgent task of modern materials science [1-4]. Interest in micro and nanoparticles of cellulose increased significantly after the discovery of possibility of expanding functional characteristics of materials in compositions with modified cellulose micro and nanoparticles $[5,6]$. Thus, the loading with cellulose particles of structural materials allows reducing their weight while maintaining the strength of composites, in particular, the filling of polymers with nanocellulose leads to an increase in the strength of biocomposites [7, 8]. Surface modification of cellulose particles by electrically conductive or photoactive compounds, such as dyes, metal oxides, silicon, allows applying composites with modified cellulose in microand optoelectronics [9-12].

It should be noted that in hybrid polymer composites, cellulose is often applied as a structural material, which, on the one hand, reduces the composite weight and, on the other side, is a reinforcing component of the material. Reinforcement is achieved by increasing the surface reactivity of micro and nanocellulose particles by grafting atomic functional groups that can chemically interact with the polymer chain atoms and enhance the polymer structure. In addition, to expand the operational performances of composites, for example, optically, biologically, and photo-active functional groups can be grafted onto the cellulose surface. In the hybrid polymer biosystems with modified cellulose their physical and chemical properties essentially depend both on the interfacial interaction of active surface sites of modified cellulose particle with atomic groups of polymer chains and the influence of polymer matrix on the interaction of atomic groups of functional modifiers with the surface centers of cellulose particles. Interfacial interaction can significantly change the polymeric matrix structure, the electron density distribution in the composites, and, accordingly, their operational parameters. Besides, the structural organization of the hybrid biosystem depends on the dispersion and surface reactivity of the organic filler. Therefore, for a controlled change in the functional parameters of created biocomposites, it is essential to know the physical behavior of hybrid biosystem under the influence of external factors. In this work as external factors acting on biocomposites the mechanical compression load, temperature field and action of aggressive environment were used.

In recent time there are three methods used to produce nanocellulose from plant matter, namely, mechanochemical [13, 14], enzymatic [15] and chemical [16]. The latter synthesis method was used in present work since it is the least energy and financially expensive. Synthetic cellulose is obtained from many cellulose-containing materials [17-21]. In this work the stalks of plant material promising for cellulose production [22] were used for the synthesis of nanocellulose.

The purpose of present work was to develop an effective environmentally friendly organosolvent method for producing nanocellulose from Miscanthus $x$ giganteus stalks to modify its surface with an optically active dye and to study the morphology of particles, chemical resistivity, mechanical and thermal properties of polymer composites with cellulose micro and nanoparticles. Wood micro sized cellulose was used to compare the surface reactivity effect of cellulose obtained from various sources on the hybrid biocomposite properties. The micro sized cellulose dispersion was chosen so that it has the order of the nanomaterial dispersion. An epoxy resin was used as the polymer matrix of composites. 


\section{MATERIALS AND METHODS}

The epoxy resin composites with both celluloses upon filling of $10 \%$ wt have been investigated. We use commercially available wood microcellulose.Microparticles of cellulose have an irregular shape with transverse sizes in the range of 50-300 $\mu \mathrm{m}$. Nanocellulose has been synthesized from cellulose obtained from Miscanthus $x$ giganteus stalks using environmentally safer organosolvent method. Organosolvcellulose was obtained in two steps. In the first stage, the miscanthus stalks are treated in a mixture of glacial acetic acid and $35 \%$ hydrogen peroxide in a volume ratio of $70: 30 \%$ at the liquid to solid ratio $10: 1$, at temperature $95 \pm 2{ }^{\circ} \mathrm{C}$ during 30-240 min. In the second step, the obtained cellulose was subjected an alkaline treatment at the liquid to solid ratio $12: 1$, at a temperature of $95 \pm 2{ }^{\circ} \mathrm{C}$ during 15 $240 \mathrm{~min}$. Alkaline treatment of organosolvmiscanthus cellulose (OMC) was washed with hot distilled water to neutral $\mathrm{pH}$ and stored in sealed packages under constant temperature conditions. The quality of parameters for obtained OMC samples were determined by standard methods [23].

To obtain nanocellulose hydrolysis of the wet OMC was carried out with a solution of sulfuric acid at a concentration of $43 \%$ and $50 \%$ at the liquid to solid ratio $10: 1$ at temperatures of 40 and $60^{\circ} \mathrm{C}$ for 30-90 minutes. The calculated amount of sulfuric acid with the relevant concentration was slowly added to flask with the OMC suspension. The reaction temperature was maintained in the range of $40-60^{\circ} \mathrm{C}$. At the end of the reaction time the hydrolysis was stopped by ten-fold dilution with distilled water and the suspension was cooled to room temperature. The hydrolyzed nanocellulose was washed three times with distilled water by centrifuging at $4000 \mathrm{rpm}$ and subsequent dialysis until neutral $\mathrm{pH}$ was reached. Ultrasonic treatment of the nanocellulose solution was performed using an ultrasonic disintegrator UZDN-A (SELMI, Ukraine) with $22 \mathrm{kHz}$ duration of 30 to $60 \mathrm{~min}$. The cellulose suspension was placed in an ice bath to prevent overheating during processing. As a result, the suspension had the appearance of uniform gel-like dispersion. The obtained particles have the form of nanofibers with transverse sizes of 10-40 $\mathrm{nm}$ and a length of several micrometers $[5,14,22]$.

Resin Eposir-7120 (Italian product) with a hardener polyethylene polyamine "PEPA" in a ratio of $6.2: 1$ was used as polymer composite matrix. To create resistant to external factors the color of polymer composites with nanocellulose the clathrochelate iron (II) dye was added in the nanocellulose dispersion [24]. For staining in red colora suspension was prepared containing $1.2 \mathrm{~g}$ nanocellulose particles in a solution of $1.5 \mathrm{mg}$ iron (II) clathrochelate in $10 \mathrm{ml}$ methylene chloride. Obtained suspension was treated by ultrasound with frequency $22 \mathrm{kHz}$ and duration $20 \mathrm{~min}$. The resulting suspension was poured into a weighed portion of epoxy resin and uniform mixing of the mixture was achieved by mechanical stirring. The residual solvent was removed sequentially by heat treatment at $40^{\circ} \mathrm{C}$ and vacuum treatment at 133.3 Pa. Then the hardener was added to the uncured epoxy resin composition with a dye. Air bubbles formed by stirring the mixture were removed from the uncured resin by vacuum at $40^{\circ} \mathrm{C}$. Samples for physical investigations were prepared from the obtained composition. The distribution of colored nanocellulose particles at the epoxy composite surface is shown in Fig. 1, where the light spots are caused by the red light emission from dye adsorbed on the nanocellulose.

The structural formula of cellulose-dye complex for cellulose macromolecule with adsorbed clathrochelate Fe (II) is presented in Fig. 2. Dye molecules bind to the surface sites of cellulose particles forming relatively strong complexes. Hydroxyl groups are surface sites forming hydrogen bonds with adsorbed molecules. Surface centers form chemical bonds after preliminary chemical activation of the surface $[25,26]$. An example of a hydrogen bond 
between the macromolecular cellulose surface site and an adsorbed dye molecule is shown in Fig. 2.

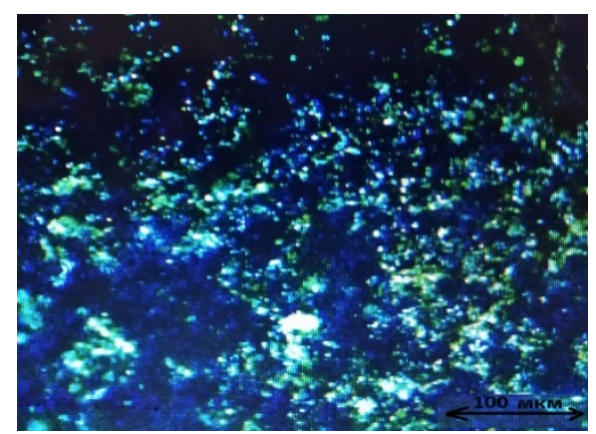

Fig. 1. Distribution of colored cellulose particles at the epoxy composite surface.

Iridescent paints are widely used to protect against the counterfeits using color copiers. Clathrochelate composite materials allow you to get an individual red "imprint" of the touch marks on the object.

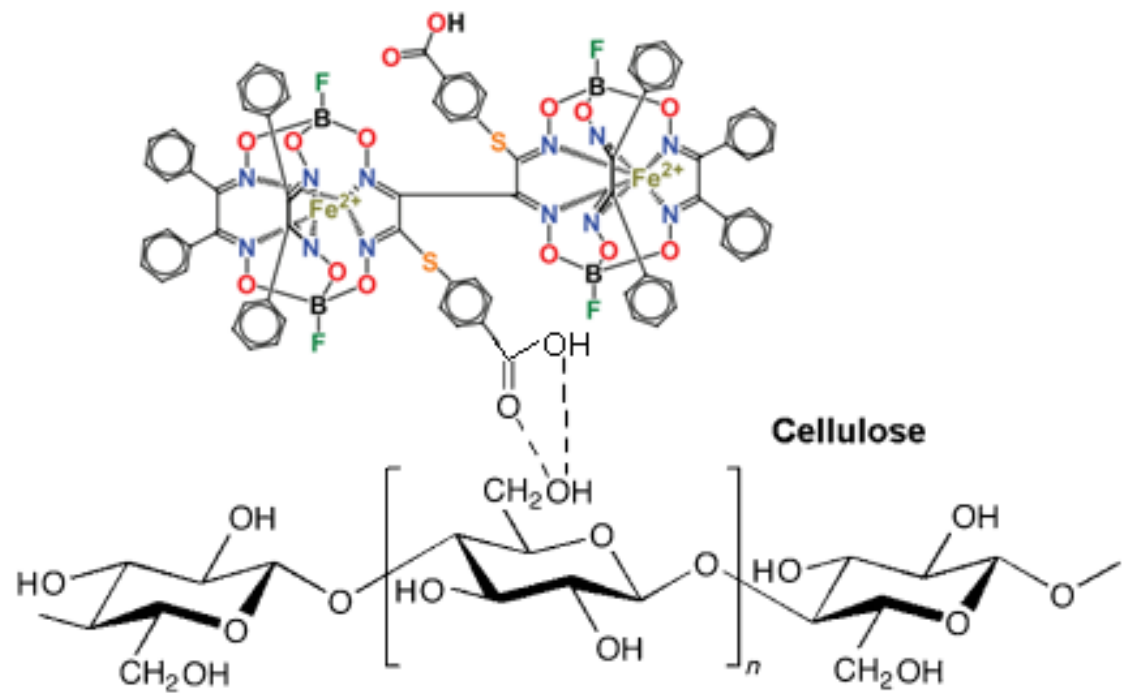

Fig. 2. Structural formula of cellulose-dye complex.

Mechanical parameters of polymer composites were determined using universal machines Shopper and UMM-10. Thermal analysis was performed using Q1500 derivatograph with heat rate $10^{\circ} \mathrm{C} / \mathrm{min}$. Swelling was determined by the gravimetric method at room temperature. Swelling was calculated as $\Delta q=q(t)-q(0)$, here $q(t)$ is the weight of samples after being in solution for time $t, q(0)$ is the sample weight before a start of swelling process. Scanning electron microscopy (SEM) was performed using a PEM-106I SELMI microscope, Ukraine.

\section{RESULTS AND DISCUSSION}

\section{Microcelluloseand nanocellulose particles distribution in epoxy matrix}

Microcellulose particles are approximately uniformly distributed in the epoxy matrix. The particle size is in the range of 50-350 $\mu \mathrm{m}$ (Fig. 3 a), and the microparticles have a developed surface with complicated morphology (Fig. 3 b). 
Fig. 4 shows a CEM image of the surface of epoxy composite with cellulose nanoparticles. It can be seen from the figure that the filler contains particles ranging in size from $1 \mu \mathrm{m}$ to large associates, consisting of several nanocellulose fibers with transverse sizes up to $10 \mu \mathrm{m}$ and a longitudinal size of up to $30 \mu \mathrm{m}$.

It should be noted that nanocellulose particles have a less developed surface compared to wood microcellulose particles (Fig. 3 b). However, measurements of the specific surface area $(s)$ by the Brunauer-Emmett-Teller method showed that the specific surface area of nanocellulose particles is $4.7 \mathrm{~m}^{2} / \mathrm{g}$ and more than 3 times exceeds the specific surface of microcellulose particles $\mathrm{s}=1.5 \mathrm{~m}^{2} / \mathrm{g}$. Coating of cellulose particles with molecules of clathrochelate $(0.1 \mathrm{wt} . \%)$ leads to a reduction in the nanocellulose specific surface to $\mathrm{s}=2.3 \mathrm{~m}^{2} / \mathrm{g}$, while the $\mathrm{s}$ value of microcellulose particles coated with clathrochelate increased to $1.9 \mathrm{~m}^{2} / \mathrm{g}$.

The decrease in the specific surface area of nanocellulose is apparently due to the fact that the cellulose agglomerates visible in Fig. 4 are globular formations of entwined cellulose nanofibers. Coating with cumbersome clathrochelate complexes of the surface of upper cellulose nanofibers forming globules overlaps the surface sites of cellulose nanofibers located inside the globules, excluding them from participation in surface reactions and reduces the specific surface of globular formations.
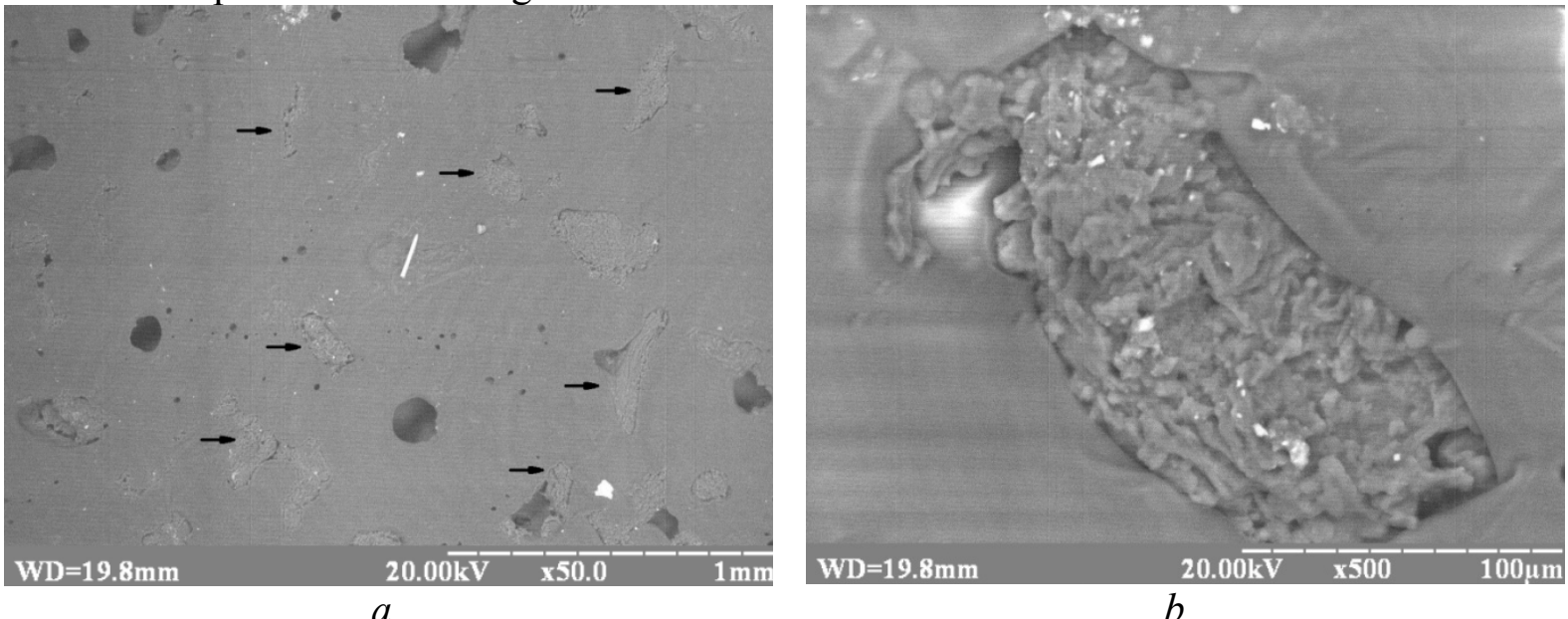

Fig. 3. CEM image of the surface layer of epoxy composite with microcellulose $(a)$ and the surface of cellulose microparticle $(b)$.

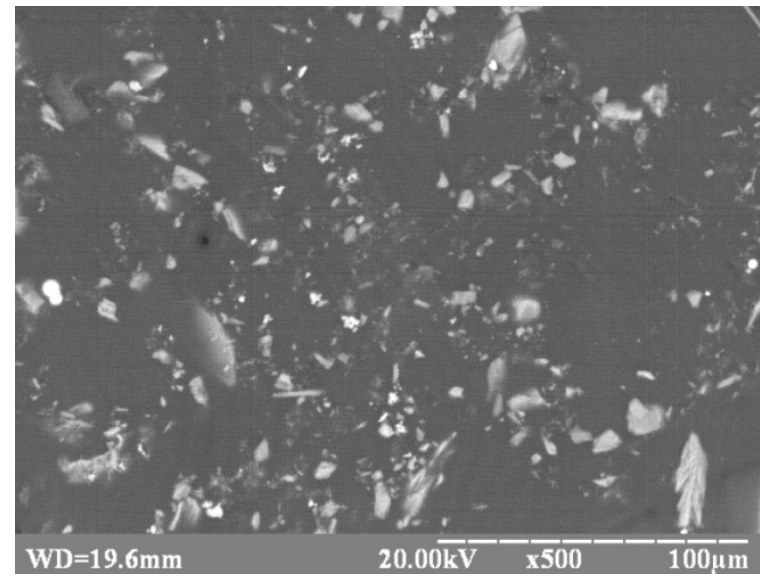

Fig. 4. CEM image of the surface layer of epoxy resin filled with nanocellulose.

The growth in the specific surface area of cellulose microparticles modified with clathrochelate is related to an increase in the surface reactivity due to oxygen and $\mathrm{OH}$ sites ofclathrochelate molecules grafted to the surface sites of microparticles (Fig. 2). 
Thus, in the epoxy matrix the high dispersion of cellulose nanoparticles is related with cellulose nanofiber globules. Particles of microcellulose do not form aggregates in the epoxy matrix.

\section{Mechanical parameters}

The elastic modulus $E$ and the compressive strength $\sigma$ have been determined from the loading curves of the epoxy resin and its composites with micro and nanocellulose. The ovalue or, in other terminology, the forced elasticity limit separating elastic and inelastic deformation regions corresponds to the $P$ extremum on the loading curves (Fig. 5).

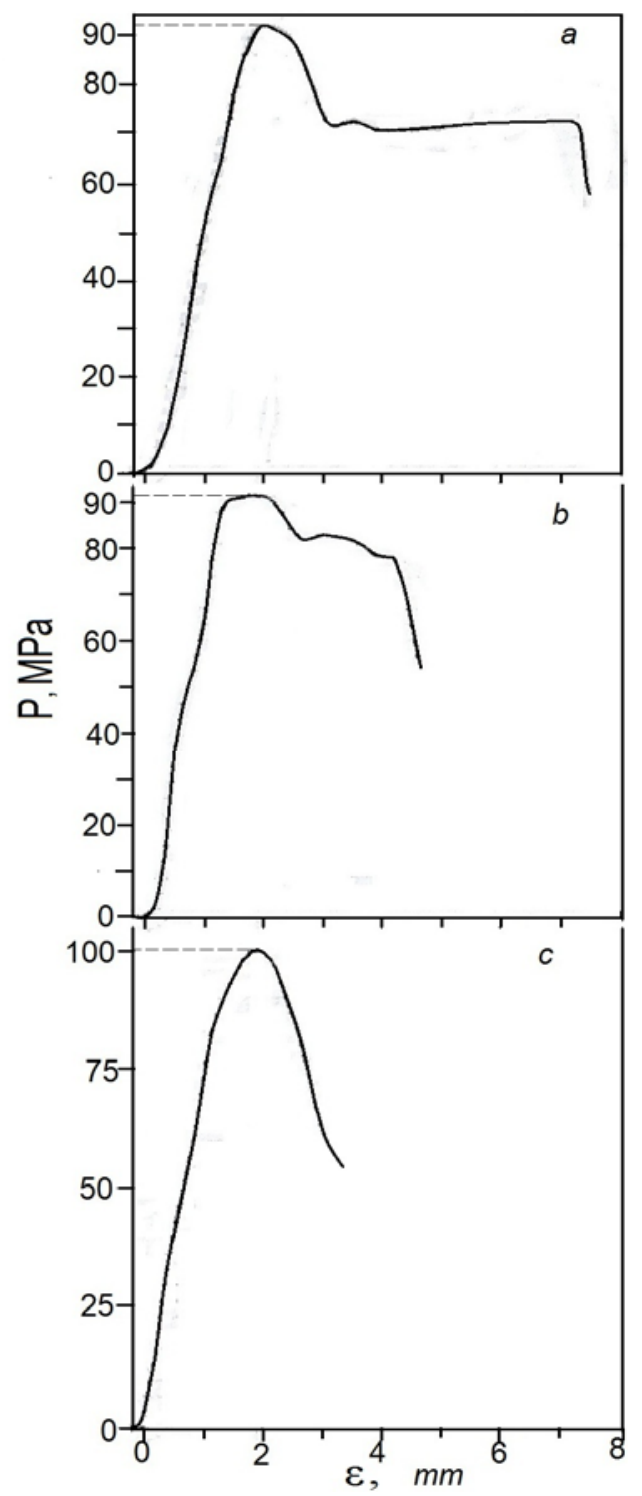

Fig. 5. Dependence of deformation of neat epoxy resin (a) and its composites with nanocellulose (b) and microcellulose (c) on loading. Dashed lines correspond to the values of the forced elasticity limit.

In unfilled resin samples the loading curves characterize by a region of elastic deformations, where the strain $\varepsilon$ linearly varies with increasing loading, and a region of conformational strains where $\varepsilon$ is weakly dependent on loading and whose volume is proportional to the polymer free volume. The elastic deformation takes place in all samples, while the volume magnitude of configurational deformations of polymer chains depends on the filler origin. The elastic modulus value for a neat resin is $1127.7 \mathrm{MPa}$, and the compressive strength value is $92.6 \mathrm{MPa}$. The introduction of nanocellulose increases the $E$ modulus to $1206.2 \mathrm{MPa}$ and practically does not affect the strength value $\sigma$ equal to 90.8 
Influence of cellulose particles on chemical resistance, mechanical and thermal properties...

MPa. In addition loading with nanocellulose lowers the region value of configurational deformations of polymer chains and the free volume magnitude in the polymer matrix (Fig. 5, b).

Filling resin with microcellulose significantly increases both the modulus $E$ to $1265 \mathrm{MPa}$ and the compressive strength to 101.5 MPa. Besides, in the matrix the free volume decreases and the configurational deformation of polymer structure is suppressed (Fig. 5, c).

Thus the loading of polymer with micro and nanocellulose particles leads to an increase in the elastic modulus of composites. The $E$ module behavior is due to the filling epoxy resin with a more plastic dispersed component and, as a consequence, a growth in the composite compressibility. Besides, the obtained nanocellulose do not have a reinforce effect on the strength of the epoxy composite. The reinforce effect of functionalized cellulose nanofibers on the strength of their compositions with epoxy resin have been observed in [27, 28]. Microcellulose particles give raises the most significant effect on the strength of composites. Such effect can be depended both on the free volume magnitude of polymer matrix and a greater surface reactivity of cellulose microparticles in comparison with the surface reactivity of nanocellulose particles. It is known [29] that the chemical bonding of polymer macromolecule atoms with the surface sites of filler particles leads to stabilization of the polymer structure and arising its strength.

To check the effect of surface state on the composite strength, the resin was filled with microcellulose particles coated with $0.1 \mathrm{wt}$ \% of clathrochelate. Coating microcellulose with clathrochelate molecules, which bind to the surface sites of microparticles (Fig. 2), increases the number of active sites and the reactivity of microcellulose surface with grafted molecules. Mechanical loading of composites with modified cellulose having a large surface reactivity shows that the growth of $E$ modulus weakens to $1206 \mathrm{MPa}$, while the strength $\sigma$ remains practically unchanged and amounts to $93.3 \mathrm{MPa}$. Besides, in composites with modified microcellulose the region of configurational deformation reveals at loading curves. Their loading curve is similar with that shown in fig 5b. Hence the behavior of composite strength does not depend on the surface reactivity of cellulose particles.

Thus, in epoxy composites their strength behavior is determined by the free volume value of polymer matrix, while variations in the elastic modulus are related to the elasticity of cellulose particles.

\section{Thermal properties}

The results of thermogravimetric analysis of the neat resin indicate that the thermal degradation of polymer occurs in the temperature range of $270-750^{\circ} \mathrm{C}$ with heat release and has a thermal oxidation character and a thermal stability of $310^{\circ} \mathrm{C}$ (at the level of mass loss of 12\%) (Fig. 6 a).

Loading resin with cellulose reduces the thermal stability of the polymer matrix, which in the nano- and micro cellulose composites is 300 and $290^{\circ} \mathrm{C}$ respectively. In addition, a reduction in heat release in a result of decomposition reactions of composites with nanocellulose by $9.0 \%$ and microcellulose by $12.0 \%$ (Fig. 6 b, c).

Thus, the filling of the epoxy polymer with micro- and nanocellulose particles reduces the thermal stability of the composite matrix and the heat release intensity in a result of thermo-oxidative destruction of the defect-free polymer structure.

The behavior of the thermal parameters of composites is due to changes in the polymer structure upon the loading with filler particles. The reduction in the thermal stability of composites is caused with an appearance of unbound fragments of polymer chains and crosslinks in the polymer structure. It is known [30] that the destruction of unbound or unfasten moieties begins at lower temperatures than the temperature of thermal decomposition for a defect-free polymer structure. Hence a decrease in the thermal stability of composites is 
related with beginning destruction of unbound fragments of polymer structure. Moreover such process is more pronounced in composites with microcellulose where the reduction in thermal stability is $20^{\circ} \mathrm{C}$.

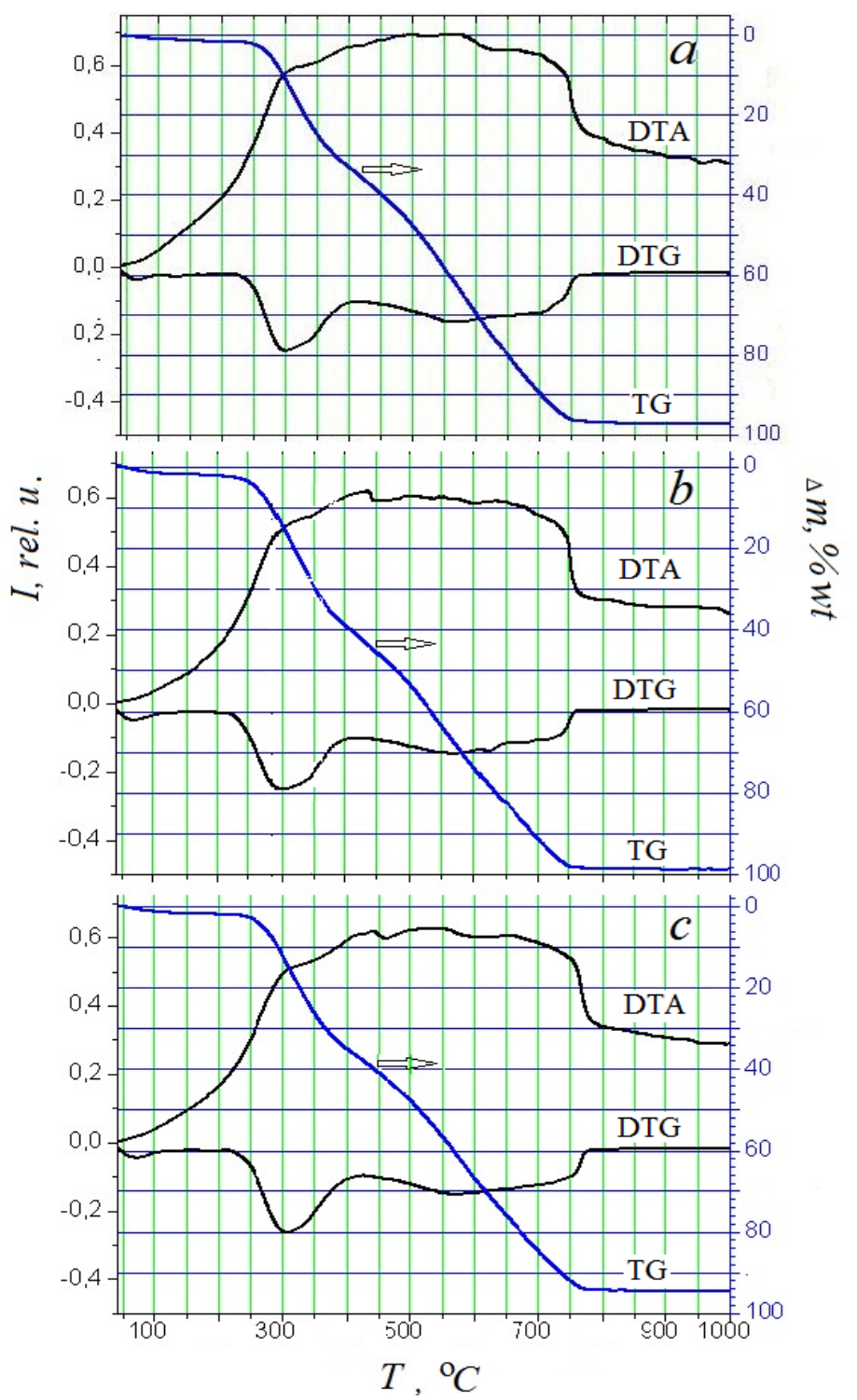

Fig. 6. Results of thermogravimetric (TG), differential thermal (DTA) and thermogravimetric (DTG) analyzes of neat resin (a) and its composites with micro- (b) and nanocellulose (c).

The appearance of unbound atomic groups and polymer structure disturbances apparently leads to diminish in the energy of intra-atomic bonds in unbound moieties and polymeric atomic groups located near polymer structure violations. Hence the destruction of the violated polymer structure occurs with releasing less heat.

\section{Chemical resistance}

The chemical resistance of materials was determined in an oxidizing medium $-35 \%$ hydrogen peroxide solution, acidic medium $-20 \%$ nitric acid solution, and neutral medium - organic solvent, acetone (analytical grade). The swelling kinetics of composites with micro and nanocellulose in an oxidizing medium indicates that the resistance of materials to swelling grows with filling and does not depend on the origin of cellulose particles and the polymer structure strength (Fig. 7). 


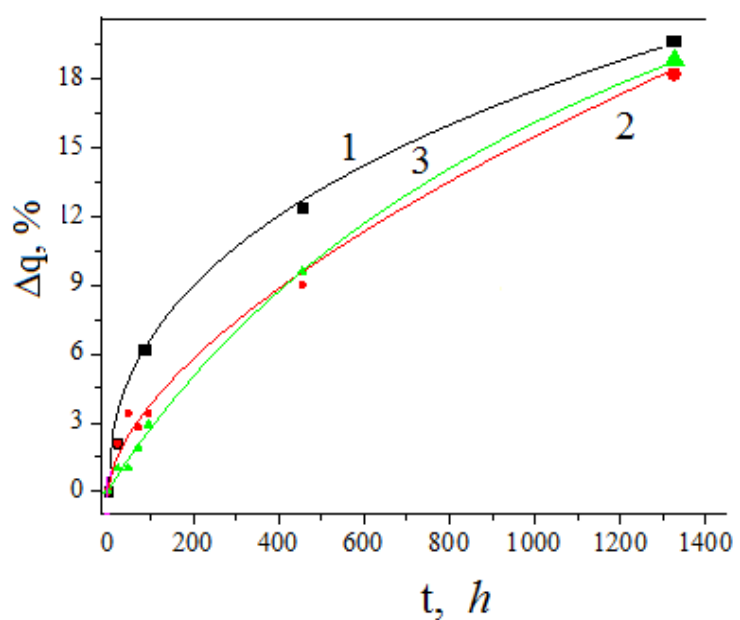

Fig. 7. Swelling curves in a $35 \%$ solution of hydrogen peroxide of neat resin (1) and its composites with nano (2) and microcellulose (3).

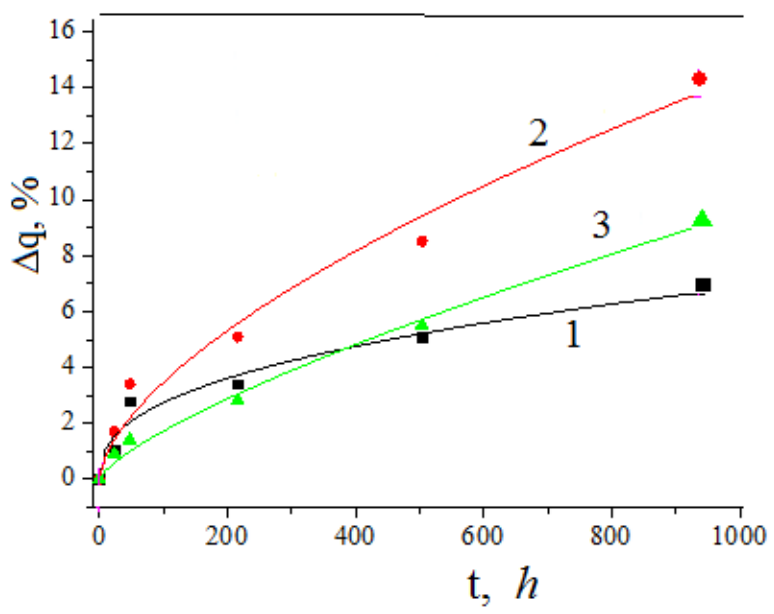

Fig. 8. Swelling curves in a $20 \%$ solution of nitric acid of neat resin (1) and its composites with nano (2) and microcellulose (3).

Curves are the exponents obtained by theoretical fitting of experimental results.

In aggressive acidic environment the chemical resistance of composites decreases (Fig. 8). In this case a correlation of $\Delta q$ with the mechanical strength of the polymer structure takes place. So the swelling of composite with nanocellulose significantly exceeds the $\Delta q$ value for the composite with microcellulose. Note that the swelling kinetics in an oxidizing and acidic medium are described by an exponential dependence, which may indicate a similar mechanism for the diffusion of hydrogen peroxide and nitric acid molecules in the composite bulk.

The swelling kinetics of neat resin and its composites with cellulose in a neutral medium characterizes by rapid absorption of acetone for 20-30 minutes. Then the slight changes in swelling for neat resin and a slow smooth increase in swelling for composites with increasing $t$. The composites with nanocellulose, for which the increase in $\Delta q$ for $480 \mathrm{~h}$ was $18 \%$, compared with the rise in $\Delta q$ for neat resin up to $23 \%$ has the highest chemical resistance to swelling. Their chemical resistance grows up $12 \%$. At the same time the chemical resistance of composites with microcellulose reduces in 12\% in compare with that for neat resin (Fig. 9).

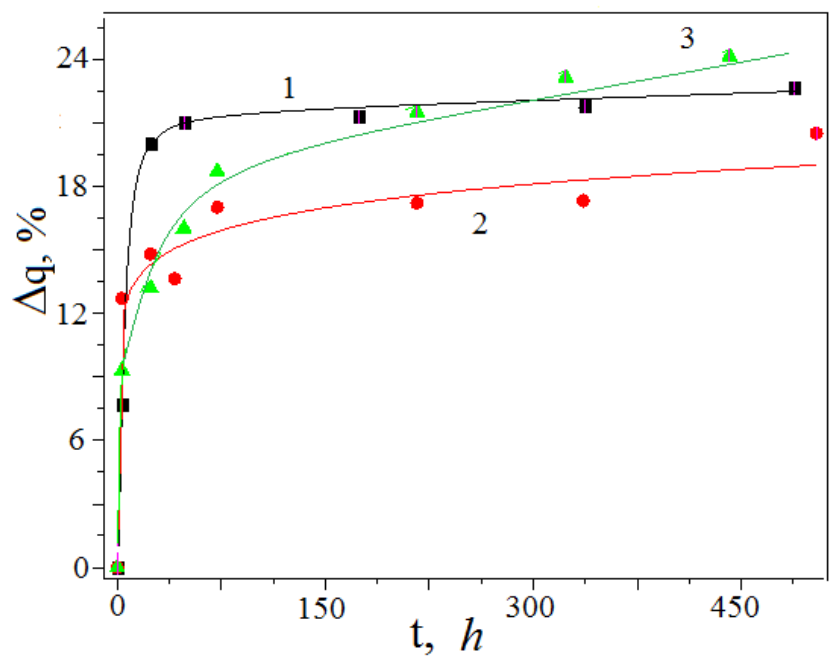

Fig. 9. Swelling kinetics in an acetone solution of neat resin (1) and its composites with nano (2) and microcellulose (3). 
Note that in the composites the swelling value in a neutral medium and its intensity significantly exceeds the $\Delta q$ values in an acidic and oxidizing environment for time of $450 \mathrm{~h}$. Thus the loading of epoxy resin with particles of micro- and nanocellulose weakly affects the chemical resistance of the composites. Composites with nanocellulose particles are most resistant to oxidizing and neutral environments.

The swelling behavior depends on the physical processes at the interface and in the polymer volume, such as the magnitudes of the surface and diffusion barriers. It can be assumed that the rapid increase in swelling in a neutral medium is due to the weak influence of the surface barrier on the embedding solvent molecules into the materialvolume and a small diffusion barrier contributing rapid filling of the polymeric free volume with solvent molecules.

\section{CONCLUSIONS}

The two-stage method for producing nanocellulose from plant materials using acid hydrolysis of organosolv cellulose was carried out, the modification of micro and nanocellulose surface with a dye was fulfilled and their compositions with epoxy resin have been obtained. Surface morphology of cellulose particles was studied.

Surface functionalization of cellulose particles with iron clathrochelate increases the surface reactivity of microcellulose particles and reduces the reactivity of the nanocellulose surface. The light response from red dye adsorbed on the surface of the cellulose particles incorporated in the epoxy matrix has been recorded. The epoxy environment does not affect the internal molecular electronic transitions in the dye.

Changes in mechanical, thermal properties and chemical resistance of composites with micro- and nanocellulose in three aggressive environments have been investigated. Loading of epoxy resin with particles of micro and nanocellulose weakly affects the chemical resistance of composites. Composites with nanocellulose are most resistant to influence of oxidizing and neutral environments.

The introduction of both types of cellulose into the epoxy resin leads to an increase in the elastic modulus of composites. However, the compressive strength in composites with microcellulose increases while in composites with microcellulose modified with dye and nanocellulose that practically does not change. The magnitudof the composite strength is related to variations in the matrix free volume upon filling and it does not depend on the surface reactivity of filler particles. The reinforcing effect of fillers increases with a free volume reduction in the composites. Filling epoxy polymer with particles of micro and nanocellulose reduces the heat resistance of the composite matrix and the intensity of heat release during thermal oxidative destruction. The influence of cellulose particles on the heat resistance of composites is attributed to appearance of unbound moieties of polymer chains in the matrix upon filling whose thermal destruction realizes with less heat release.

\section{CONFLICT OF INTERESTS}

Authors declare that a conflict of interests is absent in the paper.

\section{Authors' ORCID ID}

N.V. Sigareva (iD https://orcid.org/0000-0002-7196-6115

V.A. Barbash (iD https://orcid.org/0000-0002-7933-6038

O.V. Yashchenko (iD https://orcid.org/0000-0003-3716-8707

S.V. Shulga (iD https://orcid.org/0000-0002-9508-9110

D.L. Starokadomsky (iD https://orcid.org/0000-0001-7361-663X

B.M. Gorelov (iD https://orcid.org/0000-0002-1211-0579 


\section{REFERENCES}

1. Klemm D, Kramer F, Moritz S, Lindström T, Ankerfors M, Gray D, Dorris A. Nanocellulose: a new family of nature-based materials. Angew Chem. Int. Ed. 2011;50:5438-5466. https://doi.org/10.1002/anie.201001273

2. Dai L, Cheng T, Duan C et al. 3D printing using plant-derived cellulose and its derivatives: A review. Carbohydr. Polym. 2019;203:71-86. https://doi.org/10.1016/j.carbpol.2018.09.027

3. Sharif Hossain A, Wan Mohtar W, Veettil VN. Bioethanol production from fruit biomass as bio-antiseptic and bio-antifermenter. Journal of Applied Sciences, 2019,19:311-318. https://doi.org/10.3923/jas.2019.311.318

4. Nogi M, Iwamoto S, Nakagaito AN, Yono H. Optically transparent nanofiber paper. Adv Mater 2009;21:1595-1598. https://doi.org/10.1002/adma.200803174

5. Cruz J, Fangueiro R. Surface modification of natural fibers: A review. Procedia Engineering. 2016;155:285288. https://doi.org/10.1016/j.proeng.2016.08.030

6. Thakur VK, Thakur MK. Chemical functionalization of carbon nanomaterials. Chemistry and applications. CRC Press. 2015; 1101 p.https://doi.org/10.1201/b18724

7. Panaitescu DM, Frone AN, Ghiurea M, Spataru CI, Radovici C, Iorga MD. Properties of polymer composites with cellulose microfibrils. In book "Advances in composites materials - ecodesign and analysis" Ch.5. 2011; P. 103-122. ISBN 978-953-307-150-3

8. Poveda, RL, Gupta N. Carbon nano fiber reinforced polymer composites. Springer Briefsin Materials. 2016; 98. https://doi.org/10.1007/978-3-319-23787-9

9. Feng L, Xie N, Zhong J. Carbon nanofibers and their composites: A review. Materials Synthesizing, Properties and Applications. 2014;7:3919-3945.https://doi.org/10.3390/ma7053919

10. Thiemann S, Sachnov SJ, Pettersson F, Bollström R, Österbacka R, Wasserscheid P, Zaumseil J. Cellulosebased ionogels for paper electronics. Adv. Func. Mater. 2014;24:625-634. https://doi.org/10.1002/adfm.201302026

11. Gao K, Shao Z, Li J, Wang X, Peng X, Wang W, Wang F. Cellulose nanofiber-graphene all solid-state flexible supercapacitors. J MaterChem A 2013;1:63-67.https://doi.org/10.1039/C2TA00386D

12. Burrs SL, Bhargava M, Sidhu R, Kiernan-Lewis J, Gomes C, Claussen JC, McLamore ES. A paper based graphene-nanocauliflower hybrid composite for point of care biosensing. Biosens Bioelectron. 2016;85:479487. https://doi: 10.1016/j.bios.2016.05.037

13. AbdulKhalil HP, Davoudpour Y, Nazuruyl Islam M, Asniza M, Sudesh K, Rudi Dungani, Jawaid M. Production and modification of nanofibrillated cellulose using various mechanical processes: a review. Carbohydr. Polym. 2014;99:649-665. https://doi.org/10.1016/j.carbpol.2013.08.069

14. Barbash VA, Yaschenko OV, Alushkin SV, Kondratyuk AS, Posudievsky OY, Koshechko VG. The effect of mechanochemical treatment of the cellulose on characteristics of nanocellulose films. Nanoscale Res. Lett. 2016;11:410. https://doi.org/10.1186/s11671-016-1632-1

15. Paul B Filson, Benjamin E Dawson-Andoh, Diane Schwegler-Berry. Enzymatic-mediated production of cellulose nanocrystals from recycled pulp. Green Chemistry. 2009;11(11):1808-1814. https://doi.org/10.1039/B915746H

16. Spence KL, Venditti RA, Rojas OJ, Habibi Y, Pawlak JJ. A comparative study of energy consumption and physical properties of microfibrillated cellulose produced by different processing methods. Cellulose. 2011;18(4):1097-1111. https://doi.org/10.1007/s10570-011-9533-z

17. Sánchez R, Espinosaa E, Domínguez-Roblesa J, Mauricio Loaiza J, Rodrígueza A. Isolation and characterization of lignocellulose nanofibers from different wheat straw pulps. Int $\mathrm{J}$ of Biological Macromolecules. 2016;92:1025-1033. https://doi.org/10.1016/j.ijbiomac.2016.08.019

18. Kunaver M, Anžlovar A, Žagar E. The fast and effective isolation of nanocellulose from selected cellulosic feedstocks. CarbohydrPolym. 2016;148:251-258. https://doi.org/10.1016/j.carbpol.2016.04.076

19. Borand NM, Karaosmanoğlu F. Effects of organosolv pretreatment conditions for lignocellulosic biomass in biorefinery applications: A review. Journal of Renewable and Sustainable Energy 2018;10:033104. https://doi.org/10.1063/1.5025876

20. Correia VC, dos Santos V, Sain M, Santos SF, Leão AL, SavastanoHJr. Grinding process for the production of nanofibrillated cellulose based on unbleached and bleached bamboo organosolv pulp. Cellulose. 2016;23:2971-2987. https://doi.org/10.1007/s10570-016-0996-9

21. Paschoal GB, Muller CMO, Carvalho GM, Tischer CA, Mali S. Isolation and characterization of nanofibrillated cellulose from oat hulls. Quim Nova. 2015;38(4):478-482. https://doi.org/10.5935/01004042.20150029

22. Barbash VA, Yaschenko OV and OM Shniruk. Preparation and Properties of Nanocellulose from Organosolv Straw Pulp. Nanoscale Res. Lett. 2017;12:241-249. https://doi.org/10.1186/s11671-017-2001-4

23. TAPPI Test Methods. Atlanta, Georgia, Tappi Press, 2004. 
24. Voloshin YZ, Kostromina NA, Krämer R. Clathrochelates: synthesis, structure and properties. Amsterdam: Elsevier Science. 2002. 432 p. ISBN 9780444512239.

25. Ge Zhu and Ning Lin. SurfaceChemistryofNanocellulose. In: Huang J, Dufresne A, Lin N, editors. Nanocellulose: from fundamentals to advanced materials. Wiley-VCH Verlag GmbH \& Co. KgaA; 2019:15153. https://doi.org/10.1002/9783527807437.ch5

26. Chakrabarty A,Teramoto Y. Recent advances in nanocellulose composites with polymers: A guide for choosing partners and how to incorporate them. Polymers. 2018;10(5):517-522. https://doi.org/10.3390/polym10050517

27. Pei-Yu Kuo, Luizmar de Assis Barros, Ning Yan, Mohini Sain, Yan Qing, Yiqiang Wu. Nanocellulose composites with enhanced interfacial compatibility and mechanical properties using a hybrid-toughened epoxy matrix. Carbohydrate Polymers. 2017;177:249-257.https://doi.org/10.1016/j.carbpol.2017.08.091

28. Jabbar A, Militký J,Wiener J, Kale Bandu M, Ali U, Rwawiire S. Nanocellulose coated woven jute/green epoxy composites: Characterization of mechanical and dynamic mechanical behavior. Composite Structures. 2016; 161:340-349. https://doi.org/10.1016/j.compstruct.2016.11.062

29. Grassie N, Scott G. Polymer degradation and Stabilization. Cambridge University Press. New York.1988. 222.

30. Gorelov B, Gorb A, Korotchenkov O, Nadtochiy A, Polovina O, Sigareva N. Impact of titanium and silica/titanium and silica/titanium fumed oxide nanofillers on the elastic properties and thermal decomposition of a polyester resin. Journal of Applied Polymer Science. 2015;132(22):42010-42020. https://doi.org/10.1002/app.42010 